\title{
Review Article \\ Role of Nicotinamide in DNA Damage, Mutagenesis, and DNA Repair
}

\author{
Devita Surjana, Gary M. Halliday, and Diona L. Damian \\ Discipline of Dermatology, Sydney Cancer Centre, Bosch Institute, University of Sydney at Royal Prince Alfred Hospital, \\ Camperdown, Sydney, NSW 2006, Australia
}

Correspondence should be addressed to Gary M. Halliday, gary.halliday@sydney.edu.au

Received 16 April 2010; Accepted 13 June 2010

Academic Editor: Ashis Basu

Copyright ( 2010 Devita Surjana et al. This is an open access article distributed under the Creative Commons Attribution License, which permits unrestricted use, distribution, and reproduction in any medium, provided the original work is properly cited.

Nicotinamide is a water-soluble amide form of niacin (nicotinic acid or vitamin B3). Both niacin and nicotinamide are widely available in plant and animal foods, and niacin can also be endogenously synthesized in the liver from dietary tryptophan. Nicotinamide is also commercially available in vitamin supplements and in a range of cosmetic, hair, and skin preparations. Nicotinamide is the primary precursor of nicotinamide adenine dinucleotide $\left(\mathrm{NAD}^{+}\right)$, an essential coenzyme in ATP production and the sole substrate of the nuclear enzyme poly-ADP-ribose polymerase-1 (PARP-1). Numerous in vitro and in vivo studies have clearly shown that PARP-1 and NAD ${ }^{+}$status influence cellular responses to genotoxicity which can lead to mutagenesis and cancer formation. This paper will examine the role of nicotinamide in the protection from carcinogenesis, DNA repair, and maintenance of genomic stability.

\section{Introduction}

Nicotinamide (pyridine-3-carboxamide; Figure 1(a) is an amide active form of Vitamin B3 or niacin (pyridine-3carboxylic acid; Figure 1(b). Both nicotinamide and niacin are precursors for the synthesis of nicotinamide adenine dinucleotide $\left(\mathrm{NAD}^{+}\right)$and the phophorylated derivative $\mathrm{NADP}^{+}$[1] (Figure 2). Nicotinamide and niacin are readily available from plant and animal foods, and niacin can be endogenously synthesized from the amino acid tryptophan [2], which constitutes $\sim 1 \%$ of protein in the diet [1]. The main dietary sources of nicotinamide and niacin are various meats, liver, yeast, dairy products, legumes, beans, nuts, seeds, green leafy vegetables, fortified bread, cereals, coffee, and tea $[1,3]$. Uncooked foods mostly contain $\mathrm{NAD}^{+}$and $\mathrm{NADP}^{+}$, which can be enzymatically hydrolysed to nicotinamide in the process of cooking [1]. Studies in adult humans in the 1950s estimated that around $60 \mathrm{mg}$ of tryptophan is hepatically converted to $1 \mathrm{mg}$ of niacin, which is equal to 1 niacin equivalent (NE) [1]. Vitamins B2 (riboflavin) and B6 (pyridoxine) in addition to iron are needed as cofactors for conversion of tryptophan to niacin $[1,3]$. The ability to convert tryptophan to niacin varies greatly between individuals and is enhanced by protein and tryptophan deficiency, and it is depressed by excessive dietary leucine [1]. The adult recommended daily intake expressed as niacin equivalent is $16 \mathrm{NE} /$ day for men, $14 \mathrm{NE} /$ day for women and $18 \mathrm{NE}$ /day and $17 \mathrm{NE}$ /day for pregnant and lactating women, respectively [4]. In humans, dietary nicotinamide and niacin are absorbed from stomach and intestine via both sodium-dependent and passive diffusions [1]. Most tissues take up both forms of vitamins to synthesize $\mathrm{NAD}^{+}$and $\mathrm{NADP}^{+}$, although nicotinamide is the preferable substrate [5]. Dietary $\mathrm{NAD}^{+}$and $\mathrm{NADP}^{+}$ are hydrolyzed by intestinal mucosal and hepatic NAD glycohydrolases to release nicotinamides into the portal or systemic circulation [1]. Niacin is also endogenously synthesized from dietary tryptophan via kynurenine pathway and quinolinate (Figure 2), and this supplies most of the body's niacin requirements [1]. Niacin and quinolinate are further converted to nicotinic acid ribonucleotides and then into $\mathrm{NAD}^{+}[1]$. Excess nicotinamide and niacin are methylated in the liver to form $\mathrm{N}^{1}$-methylnicotinamide (NMN) and $\mathrm{N}^{1}$-methylnicotinic acid (NMNA), respectively [1]. NMN is further oxidised into $\mathrm{N}^{1}$-methyl-4-pyridone-3-carboxamide (4-pyr) and $\mathrm{N}^{1}$-methyl-2-pyridone-5-carboxamide (2-pyr) [1]. Niacin is also metabolized in the liver into glycine conjugate and nicotinuric acid [6]. These metabolites are 


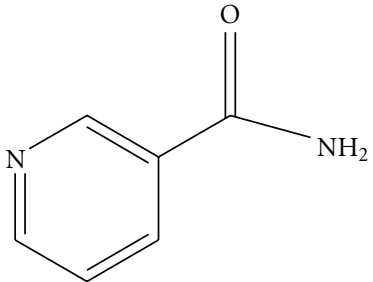

(a) Structure of nicotinamide (pyridine-3-carboxamide)

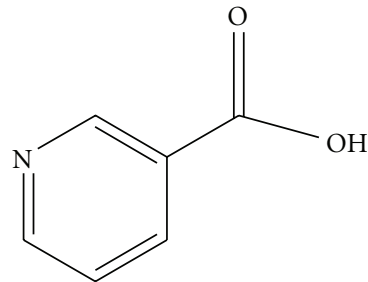

(b) Structure of nicotinic acid or niacin (pyridine-3-carboxylic acid)
Figure 1

then renally excreted [1]. Some cosmetic preparations also contain nicotinamide. Systemic absorption of topical nicotinamide has been reported to be approximately $10 \%$ depending on the vehicle used [7]. Adverse effects of nicotinamide are rare and have occurred mainly with high oral doses ( $\geq 6$ gram/day), which include nausea, vomiting, liver toxicity, headache, fatigue, and dizziness [8-10]. Unlike niacin, nicotinamide is not a vasodilator, thus it rarely causes flushing [11].

Severe nicotinamide deficiency in humans causes the disease pellagra (Italian "pelle agra"; "rough skin"), which is characterised by photosensitive dermatitis, diarrhoea, dementia, and death [3]. It was thought that the clinical manifestations of pellagra arise from the deficient $\mathrm{NAD}^{+}$ and $\mathrm{NADP}^{+}$levels in maintaining energy for cellular functions [13]. However, understanding of these multiple symptoms has progressed with the finding of $\mathrm{NAD}^{+}$as a substrate for poly(ADP-ribose)polymerases (PARPs) [14]. PARP has been recognized to play multitude roles in DNA damage responses, including DNA repair, maintenance of genomic stability, transcriptional regulation, signaling pathways involving apoptosis, telomere functions, and other multiple cellular functions [15]. Several members of the PARP family have been identified, of which PARP-1 is the most reported and is the focus of this paper. $\mathrm{NAD}^{+}$has also been shown to be a free radical scavenger [16-20] and is directly used for the synthesis of cyclic ADP-ribose, which may be involved in calcium signaling pathways leading to apoptosis or necrosis $[21,22]$. Cellular $\mathrm{NAD}^{+}$status has been increasingly demonstrated to alter the cell susceptibility to genotoxic damage [23], highlighting the crucial role of nicotinamide as a $\mathrm{NAD}^{+}$precursor in modulating pathways involved in carcinogenesis. This paper will first discuss nicotinamide and carcinogenesis in humans and whole animal models. Next, the roles of nicotinamide in relation to DNA repair, genomic stability, and mutagenesis will be examined.

\section{Nicotinamide, Niacin, and Cancer in Humans}

There are relatively few epidemiological studies on the association between nicotinamide intake and cancer in humans. Deficiency of nicotinamide and other micronutrients including riboflavin, zinc, and magnesium have been linked to the increased frequency of oesophageal cancer in certain populations in China and Italy $[24,25]$. Low dietary niacin has also been associated with an increased frequency of oral, gastric, and colon cancers, as well as oesophageal dysplasia [25-27]. In the Linxian trial in China, involving nearly 30,000 residents, $40 \mathrm{mg}$ niacin and $3.2 \mathrm{mg}$ riboflavin were supplemented in one of the treatment arms daily for over 5 years. It was shown that this combined supplementation decreased oesophageal cancer incidence and mortality by $14 \%$ and $10 \%$, respectively [24]. Most human studies have examined the dietary intake or supplementation of niacin in combination with other micronutrients [24, 25, 28-32]. The impact of niacin on human carcinogenesis is therefore confounded by the effect of other micronutrients. Analysis from a large Western population within The Malmö Diet and Cancer Study in Sweden showed that approximately $15 \%-20 \%$ of individuals in this population were niacin deficient [33]. While severe niacin deficiency resulting in pellagra is uncommon in Western populations, suboptimal niacin intake may be relevant in populations at risk such as cancer patients and individuals with high occupational or environmental exposure to genotoxic agents including ionizing radiation, ultraviolet radiation (UVR), and alkylating agents. Limited studies indicate that cancer patients are at risk of niacin deficiency $[34,35]$. In one trial involving 42 patients with various primary cancers, it was shown that $40 \%$ of these patients were niacin deficient as measured by abnormally low urine levels of the niacin metabolite $\mathrm{N}^{1}$ methylnicotinamide [34]. Chemotherapy may also depress $\mathrm{NAD}^{+}$levels [35] and precipitate pellagra by promoting anorexia and malabsorption. Some chemotherapeutic agents (e.g., 5-fluorouracil, 6-mercaptopurine) also interfere with tryptophan conversion to niacin [36]. Moreover, chemotherapeutic alkylating agents have been shown to cause miscoding lesions, chromosomal aberrations [37], and secondary cancer, particularly leukemia, which complicates chemotherapy in $10 \%-15 \%$ of cancer survivals [38]. More direct evidence comes from studies in rats, which showed that niacin deficiency significantly increases the risk of chemotherapeutic-induced secondary leukemia [39]. Niacin and $\mathrm{NAD}^{+}$levels are important determinants of genomic responses to genotoxic insults [23]. Maintaining an optimum nicotinamide level is therefore essential in cancer patients and individuals at risk of exposure to genotoxic agents.

\section{Nicotinamide Supplementation and Animal Models of Carcinogenesis}

Animal models show that nicotinamide supplements influence carcinogenesis in a dose-dependent and organ-specific manner (Table 1). Nicotinamide is not carcinogenic by itself at doses more than 300-fold above requirement, administered to mice throughout their life span [40]. Overall, low-dose nicotinamide (dose range of $150-200 \mu \mathrm{M}$, topical; $0.25 \%-2.5 \%$, oral; $30 \mathrm{mg} / \mathrm{kg}$ body weight (bw) intraperitoneal) appears to be protective in various chemical- and UVR-induced carcinogenesis models in animals. Nicotinamide at dietary concentrations of $0.25 \%-2.5 \%$ is protective against urethane-induced pulmonary adenoma in 


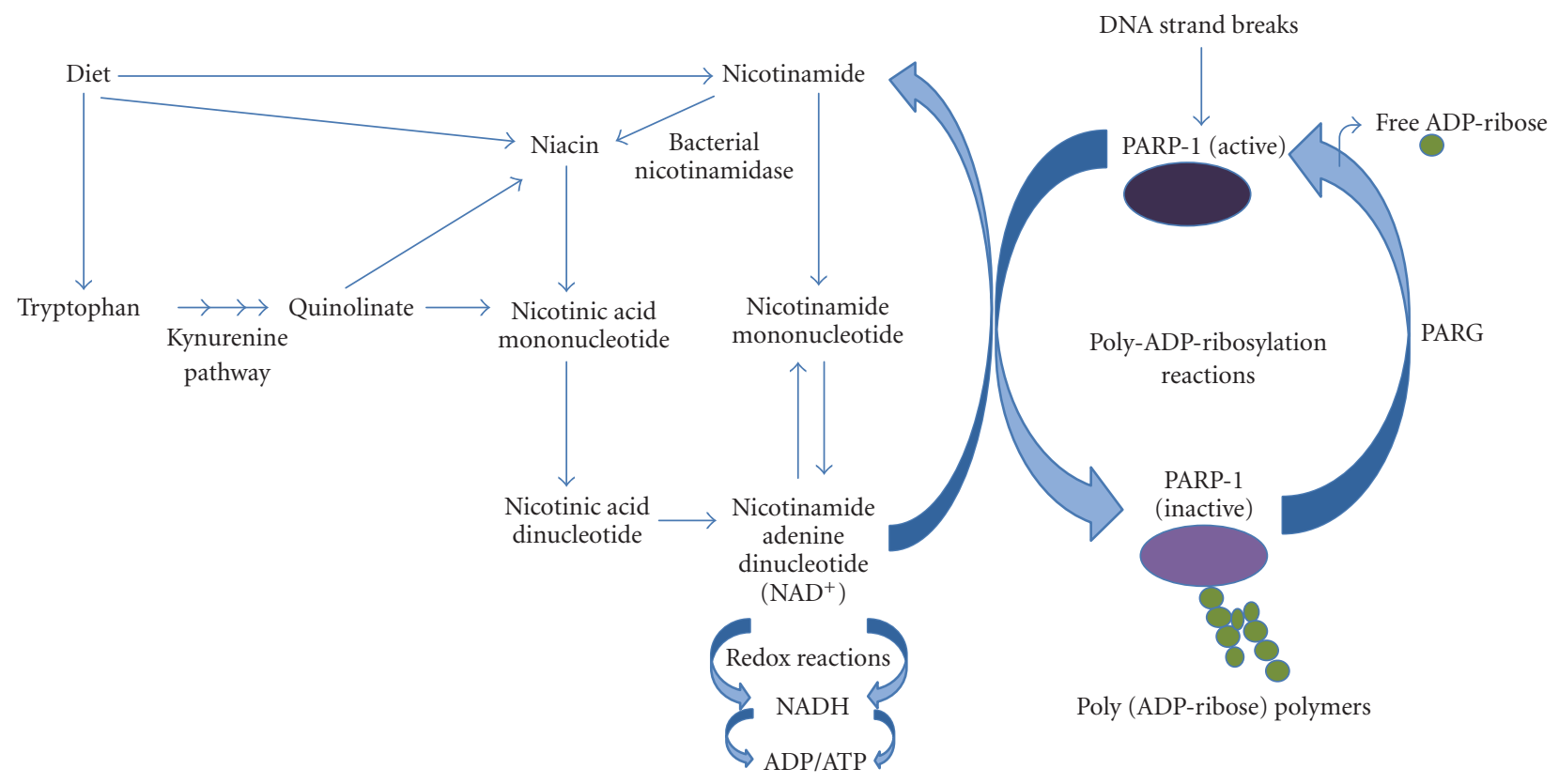

Figure 2: The simplified pathways for nicotinamide, niacin, NAD ${ }^{+}$, and PARP-1 metabolism. Dietary nicotinamide, niacin, and tryptophan are precursors for the synthesis of $\mathrm{NAD}^{+}$, essential in ATP production and PARP-1 activation. Nicotinamide can be converted to niacin by bacterial nicotinamidase in the intestinal lumen. PARP-1 is activated by DNA strand breaks, cleaving NAD ${ }^{+}$into nicotinamide and ADP-ribose. Poly(ADP-ribose) glycohydrolase (PARG) reactivates PARP-1 by removing poly(ADP-ribose) polymers, allowing for continuous $\mathrm{NAD}^{+}$utilization. Figure is adapted from Jacobson et al., in 1995 [6] and Meyer-Ficca et al., in 2004 [12].

mice, whereas $0.25 \%$ niacin did not show the same protection $[41,42]$. However, higher concentrations of dietary niacin $(0.4 \%)$ caused a $6 \%$ reduction in the incidence of nonlymphocytic leukemia induced by ethylnitrosourea in Weanling male Long-Evans rats [43]. Nicotinamide has also been shown to inhibit the growth of transplanted murine breast adenocarcinoma in mice, although the doses required are higher $(2.5 \%$ and $5 \%$ diet; $1000 \mathrm{mg} / \mathrm{kg}$ bw intraperitoneal) than those needed to suppress carcinogeninduced cancers $[44,45]$. The effect of nicotinamide on diethylnitrosamine (DEN)-, streptozotocin-, and heliotrineinduced carcinogenesis seems to be organ-specific. Massive doses of nicotinamide $(350-500 \mathrm{mg} / \mathrm{kg}$ bw intraperitoneal, multiple dosing) inhibited DEN-induced liver tumours (34\% reduction), but promoted DEN-induced kidney neoplasia (44\% increase) in Wistar rats [46]. However, in another study of DEN-induced carcinogenesis, even low-dose nicotinamide $(0.082 \%$ and $0.37 \%$ oral $)$ increased the incidence of DENinduced kidney tumours from $5 \%$ in controls (DEN only) to $28 \%$ and $59 \%$, respectively, in male F344 rats [47]. $0.37 \%$ nicotinamide by itself had no effect on tumour formation [47], suggesting that the presence of carcinogen is required for the tumour promoting or inhibiting effect of nicotinamide.

Intraperitoneal nicotinamide $(350 \mathrm{mg} / \mathrm{kg})$ increased the incidence of streptozotocin-induced pancreatic islet-cell tumours in male Holtzman rats from $4 \%$ in controls (streptozotocin only) to 64\% [48], but it decreased the incidence of renal adenomas from $77 \%$ to $18 \%$ [49]. Nicotinamide administered intraperitoneally at $500 \mathrm{mg} / \mathrm{kg}$ to white male weanling rats before and after administration of pyrrollizidine alkaloid heliotrine increased pancreatic isletcell tumours [50]. The varying effects of nicotinamide with different carcinogens and target organs may reflect the differential susceptibility of each organ to DNA damaging agents. Furthermore, it has been shown that PARP-1 protein expression is tissue- and/ or cell-type specific [51], and there are tissue and species differences in requirements for $\mathrm{NAD}^{+}$precursors. Tissues with high cellular turnover including breast, lung, and skin have higher $\mathrm{NAD}^{+}$requirements, and mice are relatively more resistant to niacin deficiency compared to rats or humans [23]. Hence, the breast, lung, and skin tissues of rats and humans likely required higher doses of $\mathrm{NAD}^{+}$precursors in the face of genomic insults.

\section{Nicotinamide: Photoimmunosuppression and Skin Cancer}

The immune system is an important defense mechanism that prevents potentially cancerous cells from developing into tumors. In humans, the importance of immunity in preventing cancer is observed in renal transplant recipients on immunosuppressive medications. In this population, there is an increased incidence of all cancer type (13.7fold increase), nonmelanoma skin cancer (33-fold increase), and melanoma (3.3-fold increase) compared to age-matched immune competent individuals [58]. Ultraviolet (UV) radiation in sunlight is the primary initiator of skin cancer by 
TABLe 1: Animal models of nicotinamide or niacin effect on carcinogenesis.

\begin{tabular}{|c|c|c|c|c|c|}
\hline Animal & Carcinogen & $\begin{array}{l}\text { Form of nicotinamide } \\
\text { (dose) }\end{array}$ & Organ & Effect on tumor & Ref. \\
\hline Mouse & None & Oral & All & None & {$[40]$} \\
\hline Mouse & UV & $\operatorname{Topical}(200 \mu \mathrm{M})$ & Skin & Inhibition & [52] \\
\hline Mouse & UVB & $\begin{array}{l}\text { Oral (niacin })(0.5 \% ; 1 \% \\
\text { diet })\end{array}$ & Skin & Inhibition & [53] \\
\hline Mouse & TPA & Topical $(150 \mu \mathrm{M})$ & Skin & Inhibition & {$[54]$} \\
\hline Mouse & DMBA and Croton oil & $\operatorname{Oral}(0.2 \%$ diet $)$ & Skin & None & [55] \\
\hline Mouse & Urethane & $\begin{array}{l}\text { Oral }(0.25 \% ; 0.4 \% \text { diet }) \\
\text { Oral (niacin) }(0.25 \% \text { diet })\end{array}$ & $\begin{array}{l}\text { Lung } \\
\text { Lung }\end{array}$ & $\begin{array}{l}\text { Inhibition } \\
\text { None }\end{array}$ & {$[41]$} \\
\hline Mouse & Urethane & Oral ( $1 \% ; 2.5 \%$ diet $)$ & Lung & Inhibition & [42] \\
\hline Rat & ENU & Oral (niacin) (0.4\% diet) & $\begin{array}{c}\text { Bone marrow } \\
\text { (haemopoeitic cells) }\end{array}$ & Inhibition & [43] \\
\hline Rat & Bracken fern & Oral $(0.5 \%$ diet $)$ & $\begin{array}{l}\text { Intestine } \\
\text { Bladder }\end{array}$ & $\begin{array}{l}\text { Inhibition } \\
\text { Inhibition }\end{array}$ & {$[56]$} \\
\hline Hamster & $\mathrm{BOB}$ & ip $(30 \mathrm{mg} / \mathrm{kg}$ bw) & Pancreas & Inhibition & [57] \\
\hline Rat & DEN & ip $(350-500 \mathrm{mg} / \mathrm{kg} \mathrm{bw})$ & $\begin{array}{l}\text { Kidney } \\
\text { Liver }\end{array}$ & $\begin{array}{l}\text { Increase } \\
\text { Inhibition }\end{array}$ & {$[46]$} \\
\hline Rat & DEN & Oral $(0.082 \% ; 0.37 \%)$ & Kidney & Increase & [47] \\
\hline Rat & Streptozotocin & ip (350 mg/kg bw) & Pancreas & Increase & [48] \\
\hline Rat & Streptozotocin & ip (350 mg/kg bw) & Kidney & Inhibition & [49] \\
\hline Rat & Heliotrine & ip $(500 \mathrm{mg} / \mathrm{kg}$ bw) & Pancreas & Increase & {$[50]$} \\
\hline Mouse & $\begin{array}{c}\text { Transplanted murine } \\
\text { breast adenocarcinoma }\end{array}$ & Oral $(2.5 \% ; 5 \%)$ & $\begin{array}{l}\text { Recipient subcutaneous } \\
\text { tissue }\end{array}$ & Inhibition & {$[44]$} \\
\hline Mouse & $\begin{array}{c}\text { Transplanted murine } \\
\text { breast adenocarcinoma }\end{array}$ & ip (1000 mg/kg bw) & $\begin{array}{l}\text { Recipient subcutaneous } \\
\text { tissue }\end{array}$ & Inhibition & {$[45]$} \\
\hline
\end{tabular}

causing DNA damage in the skin and also by suppressing cutaneous immunity, even at exposure doses $25 \%$ to $50 \%$ of those required to cause mild sunburn [59]. Both UVB (290$320 \mathrm{~nm})$ and UVA (320-400 nm) in sunlight are immune suppressive [60, 61]. UV-induced DNA damage, particularly in the form of cyclobutane pyrimidine dimers (CPDs), is an important molecular trigger for UV-induced immunosuppression [62]. Agents that can modulate DNA repair and prevent UV-induced immunosuppression may thus reduce skin cancer.

In mice, $200 \mu \mathrm{M}$ topical nicotinamide [52] and $0.5 \%$ and $1 \%$ niacin-supplemented diets [53] have both been shown to markedly protect against UV-induced immunosuppression and significantly reduce the incidence of UV-induced skin tumours. In these studies, UV-induced immunosuppression was measured by passive transfer assay, whereby splenocytes from irradiated mice enhanced the growth of antigenic tumours in unirradiated, recipient mice [52, 53]. Topical nicotinamide also slowed down the rate of skin tumour development [52] and the effect of oral niacin on tumour inhibition was greater with increasing dose [53]. Oral niacin increased skin $\mathrm{NAD}^{+}$levels, which were reduced by UVR in mice not receiving niacin, and this was thought to contribute to tumour prevention $[52,53]$. It was also suggested that protection from photoimmunosuppression is a mechanism by which nicotinamide and niacin prevent UV-induced carcinogenesis $[52,53]$.
Using the Mantoux model of delayed-type hypersensitivity (DTH) in healthy volunteers, we have shown that nicotinamide protects from UV-induced immunosuppression in humans $[63,64] .5 \%$ topical nicotinamide, applied 15 minutes before or after each of 3 daily exposures to low-dose solar-simulated (ss) UV (equivalent to less than $\sim 8$ minutes exposure to Sydney spring sunlight [65]), prevented UVinduced suppression of Mantoux reactions [63]. 5\% topical nicotinamide, applied immediately after a single exposure to narrowband UVB (300 nm) or UVA (385 nm), protected against immunosuppression by both wavebands [66]. Using the same model, oral nicotinamide has also been shown to protect skin immunity in humans [64].

\section{Nicotinamide, PARP-1 and DNA Repair}

The role of nicotinamide in DNA repair and maintenance of genomic stability is tightly related to its functions as an $\mathrm{NAD}^{+}$precursor and a substrate for PARP-1. PARP1 is a nuclear enzyme which detects DNA damage, binds to DNA single or double strand breaks, and then uses $\mathrm{NAD}^{+}$as a substrate to form nicotinamide and ADPribose. Subsequent enzymatic reactions lead to the formation of branched ADP-ribose polymers on a nuclear acceptor protein [67, 68] (Figure 2). Poly(ADP-ribosylation) of the acceptor protein has been hypothesized to function in DNA repair by modifying structural proteins proximal to DNA 
strand breaks, facilitating the opening of the condensed chromatin structure, which is required for the recruitment of DNA repair complexes $[69,70]$. The major acceptor proteins of poly(ADP-ribose) are PARP-1 itself, and auto-poly(ADPribosylation) results in downregulation of the enzyme [70]. Other major acceptor proteins reported are histone, topoisomerase I and II, DNA polymerase $\alpha$ and $\beta$, DNA ligase I and II, nuclear retinoid $\mathrm{X}$ receptor, nuclear factor $(\mathrm{NF})-\kappa \mathrm{B}$, and p53 [70, 71]. Poly(ADP-ribose) glycohydrolase (PARG) is the main enzyme involved in catabolism of poly(ADPribose), cleaving it into free ADP-ribose monomers [70]. PARP-1 itself is also known to be part of chromatin structure and involved in maintaining a compact chromatin structure, preventing inadvertent transcription from occurring [72]. Unfolding of the compact chromatin structure allows DNA regulatory and repair processes access to the damaged sites as well as to replication and transcription initiation sites [73]. PARP-1 has been reported to play a key role in the nucleotide excision repair (NER) pathway used to remove bulky DNA adducts [74] and in the base excision repair (BER) pathway by interacting with BER protein XRCC1 (X-ray repair crosscomplementing 1) [75-78]. PARP-1 is involved in maintaining chromosomal integrity by protecting broken DNA from inappropriate homologous recombination during DNA repair and replication $[79,80]$. PARP knockout mice exhibited dramatically increased sensitivity to ionizing radiation and alkylating agents [81-83] and showed a 2-3-fold increase in spontaneous sister chromatid exchange (SCE) and amplified SCE and micronuclei (MN) formation induced by carcinogens $[83,84]$. PARP-null mice also showed extreme sensitivity to nitrosamine-induced carcinogenesis [85], had shorter telomeres, and increased end-to-end chromosomal fusions, aneuploid cells, and chromosome fragments [86]. Thus, nicotinamide is involved in maintenance of genomic stability by providing a substrate for PARP-1, preserving a cellular energy reserve for ATP-dependent DNA repair [87] and enabling preservation of PARP-1 integrity [88].

\section{The Influence of $\mathrm{NAD}^{+}$Status on Genomic Stability and DNA Repair}

6.1. In Vitro Studies. A large number of in vitro studies reported that $\mathrm{NAD}^{+}$status influences genomic stability and sensitivity to cytotoxic effects of DNA-damaging agents. Nicotinamide $(50-500 \mu \mathrm{M})$ increased intracellular $\mathrm{NAD}^{+}$ and enhanced the repair of DNA damage induced by $\mathrm{N}$ methyl- $\mathrm{N}^{\prime}$-nitro-N-nitrosoguanidine (MNNG) in cultured primary human mammary epithelial cells [23]. Preincubation with $74 \mu \mathrm{M}$ nicotinamide prevented $\mathrm{NAD}^{+}$depletion after dimethyl sulphate (DMS) exposure and increased strand break rejoining rate [89]. Increasing $\mathrm{NAD}^{+}$status by the addition of nicotinamide thus improved the capacity of DNA repair. $\mathrm{NAD}^{+}$is also an important determinant of skin cell survival following UV radiation. 0.1 and $33 \mu \mathrm{M}$ nicotinamide added to UV-irradiated cultured human skin fibroblasts increased cell survival 7 days post irradiation in a dose-dependent manner [90]. Even in the absence of genotoxic stress, $\mathrm{NAD}^{+}$depletion increased spontaneous
DNA damage in human HaCaT keratinocytes, which was reversible with the addition of nicotinamide [91]. $\mathrm{NAD}^{+}$ status is therefore critical in preserving genomic function of skin cells. Furthermore, it was shown that skin $\mathrm{NAD}^{+}$ levels are negatively correlated with malignant phenotype in human skin cancers. Normal skin from patients with premalignant actinic keratoses had significantly higher $\mathrm{NAD}^{+}$ than normal skin from patients with cutaneous squamous cell cancers [23].

Exposure of ex vivo human lymphocytes to oxygen radicals [92], UVB [93, 94], $\Upsilon$-irradiation [95], N-methyl$\mathrm{N}^{\prime}$-nitro-N-nitrosoguanidine (MNNG) $[93,94]$, or dimethyl sulfate (DMS)[93] resulted in reduced intracellular $\mathrm{NAD}^{+}$, with numbers of DNA-strand breaks inversely correlated with $\mathrm{NAD}^{+}$levels [92]. Addition of $2-5 \mathrm{mM}$ nicotinamide prevented this lowering of $\mathrm{NAD}^{+}$levels, stimulated unscheduled DNA synthesis (UDS), and increased DNA repair [9395]. The ability of nicotinamide to enhance DNA repair depends on the presence of functional repair mechanisms. Xeroderma pigmentosum is an autosomal recessive genetic disorder of DNA repair, in which the ability to repair DNA damage caused by UVR is deficient. [96]. In the presence of $2 \mathrm{mM}$ nicotinamide, lymphoctyes from these patients exhibited increased UDS after MNNG treatment but failed to show increased UDS after UVB irradiation. Normal lymphocytes incubated with the same dose of nicotinamide, in contrast, showed increased UDS and enhancement of DNA repair after UVB or MNND exposures [97].

In $\mathrm{HaCaT}$ cells (human keratinocyte cell line) $\mathrm{NAD}^{+}$ depletion upregulated NADPH oxidase activity with consequent increase in reactive oxygen species (ROS) production. $\mathrm{NAD}^{+}$repletion with nicotinamide completely reversed the ROS accumulation [91]. In support of these findings, niacin deficiency, which results in intracellular $\mathrm{NAD}^{+}$depletion in rats, also caused an increase in both protein carbonyls and 8-oxo-7,8-dihydro- $2^{\prime}$-deoxyguanosine (8-oxo-dG) in bone marrow [98]. Oxidative-induced DNA damage 8oxo-dG is a miscoding lesion, which generates $\mathrm{GC} \rightarrow \mathrm{TA}$ transversion mutations by pairing with an adenine instead of a cytosine during replication [99]. ROS also damages other cellular components including cell membranes by peroxidation of fatty acids within the phospholipid bilayer and proteins by forming carbonyl derivatives [100]. Lipid peroxidation increases production of prostaglandins (PG), including PGE2, which is known to play an important role in inflammation. Inflammation in premalignant actinic keratoses has been reported to be a marker of progression to squamous cell carcinoma [101]. It was also postulated that ROS may cause gene mutations in actinic keratoses, driving their progression to squamous cell carcinoma [101]. Regulation of ROS levels by maintenance of intracellular $\mathrm{NAD}^{+}$is therefore important in preventing oxidative DNA damage and gene mutation.

6.2. In Vivo Studies. Administration of $100 \mathrm{mg} /$ day niacin to two volunteers for 8 weeks protected against ex vivo lymphocyte DNA strand breaks induced by hypoxanthine/xanthine oxidase. The supplementation increased $\mathrm{NAD}^{+}$concentrations by nearly 5 times baseline levels and significantly 
reduced oxygen radical-induced DNA stand breaks in the lymphocytes [92].

The impact of niacin deficiency in rats has been extensively studied by the Kirkland group [98, 102-106]. Wenling Long-Evans rats were kept niacin-deficient (ND) or were pair-fed $(\mathrm{PF})$ either normal dietary niacin or supplemental $4 \mathrm{mg} /$ gram niacin (NA) (0.4\% of diet). The DNAalkylating agent ethylnitrosurea (ENU) or the topoisomerase II inhibitor etoposide (ETO) was then administered to these rats orally. Bone marrow is a good indicator of niacin intake. ND diets caused $72 \%-80 \%[102,104]$ reduction in bone marrow $\mathrm{NAD}^{+}$content, whereas NA diets produced a $240 \%$ increase [103]. Basal poly(ADP-ribose) levels were also significantly lower in ND rats. After ENU- or ETOtreatment, poly(ADP-ribose) levels were not increased in bone marrow of ND rats whereas in PF and NA rats, the level of bone marrow poly(ADP-ribose) rose significantly [102, 104]. Adequate $\mathrm{NAD}^{+}$is therefore essential for the increase in ADP-ribose polymer metabolism activated by DNA damage. Niacin deficiency alone causes increased micronuclei (MN) formation (6.2-fold), SCE frequency (2.8-fold) [103], chromosomes breaks (4-fold), and chromatid breaks (2fold). With ENU- or ETO-treatment, there were much greater increases in MN formation, SCE, and chromosomal aberrations (CA) in bone marrow of ND rats $[103,105]$. The increased genomic instability in ND rats is further evidenced by the reduction in latency and the increase in the incidence of developing ENU-induced leukemia [102]. Niacin deficiency significantly delayed DNA repair in bone marrow after ENU- or ETO-treatment $[103,105]$ and was shown to alter $\mathrm{p} 53$ expression and impair ETO-induced cell cycle arrest and apoptosis [104].

\section{Nicotinamide, PARP-1, and Cellular Responses to DNA Damage}

The activation of PARP- 1 by DNA strand breaks can lead to three cellular pathways depending on the intensity of DNAdamaging stimuli [70] (Figure 3). In the case of relatively mild DNA damage, PARP-1 activation enhances DNA repair by interacting with p53 protein, signaling cell-cycle arrest, and facilitating DNA repair enzymes, including XRCC1 and DNA-dependent protein kinases to access damaged DNA [70]. When DNA damage is irreparable, PARP-1 activation induces apoptotic cell death by activating NF- $\kappa$ B pathway and preventing ATP depletion and DNA repair through caspase-mediated PARP-1 cleavage [70, 107]. In contrast, extensive DNA damage leads to PARP-1 overactivation, depleting its substrate $\left(\mathrm{NAD}^{+}\right)$. As cells consume ATP in an attempt to replenish $\mathrm{NAD}^{+}$, this leads to a cellular energy crisis, which precipitates necrotic cell death [70]. Apoptosis is an energy-dependent process [108-111] thus cells severely deficient in energy are unable to proceed through apoptotic cell death.

PARP-1 is inhibited by nicotinamide and its analogues such as 3 -aminobenzamide and metoclopramide $[112,113]$. PARP-1 inhibition by nicotinamide in vitro has been reported to delay the rejoining of DNA strand breaks $[95,114,115]$, induce UDS $[95,97,116]$, and increase the frequency of spontaneous SCE $[117,118]$. It has been suggested that high dose of nicotinamide ( $5 \mathrm{mM}$ or more) inhibits DNA repair through PARP-1 inhibition while low dose nicotinamide enhances rejoining of DNA strand breaks through provision of $\mathrm{NAD}^{+}$[114]. However, it is argued that nicotinamide is unlikely to inhibit PARP in vivo [119]. Rats fed nicotinamide 33 times above normal requirements exhibited 2fold increases in basal poly(ADP-ribose). After exposure to a hepatocarcinogen, induction of poly(ADP-ribose) was only marginally higher in the nicotinamide supplemented rats [120], suggesting that a much higher dose of nicotinamide is required to possibly inhibit PARP-1 in the whole organism.

Excessive PARP activity is however detrimental to cells. Augmented PARP activity caused by reactive oxygen injury to cultured pulmonary-artery endothelial cells resulted in $\mathrm{NAD}^{+}$and ATP depletion and necrotic cell death, which was prevented by the PARP-1 inhibitors nicotinamide and 3-aminobenzamide (3-AB) [121]. Ex vivo murine lung exposed to bleomycin, a DNA-cleaving antitumor antibiotic, caused acute lung injury through sustained PARP activation and $\mathrm{NAD}^{+}$depletion. This injury was prevented in the presence of 3-AB [122]. The topical PARP inhibitor, BGP-15M (O-(3-pyperidino-2-hydroxy-1-propyl) pyrimide-3-carbocylic acid amidoxime monohydrochloride) reduced UVB-induced DNA strand breaks in hairless mouse skin and prevented excessive production of poly(ADPribose) induced by moderate UV doses. These findings suggest that the inhibition of PARP-1 overactivation, and therefore of $\mathrm{NAD}^{+}$and ATP depletion, can occur without negative consequence to DNA repair [123].

PARP-1 inhibition by nicotinamide has been shown to switch the mode of cell death from necrosis to apoptosis in ex vivo human lymphocytes treated with hydrogen peroxide [124]. In addition, it has been widely reported that in the cells exposed to oxidative stress, both ATP and $\mathrm{NAD}^{+}$levels serve as crucial molecular switches between apoptosis and necrosis [125-133]. Nicotinamide as a precursor of $\mathrm{NAD}^{+}$, ATP, and as an endogenous inhibitor of PARP-1 therefore plays significant roles in cellular protection and in determining cellular fate in response to genotoxic DNA damage.

\section{Nicotinamide, PARP-1, and Regulation of Gene Expression}

PARP-1 has been reported to frequently associate with transcriptionally active regions of chromatin [134, 135]. PARP-1 is a transcription coactivator of nuclear factor- $\kappa \mathrm{B}(\mathrm{NF}-\kappa \mathrm{B})$ [136], a transcription factor that plays a significant role in regulation of genes involved in a variety of cellular processes including immune and inflammatory responses, apoptosis, cell proliferation, and differentiation $[137,138]$. There is a large amount of literature supporting the involvement of $\mathrm{NF}-\kappa \mathrm{B}$ in cutaneous carcinogenesis $[136,139]$. Epidermal inflammation promotes tumor progression [101] and NF- $\kappa \mathrm{B}$ is known to be one of the mediators involved [139]. PARP1 knockout mice are much less sensitive to inflammatory stress $[140,141]$ and PARP-1 deficient mice exhibited 


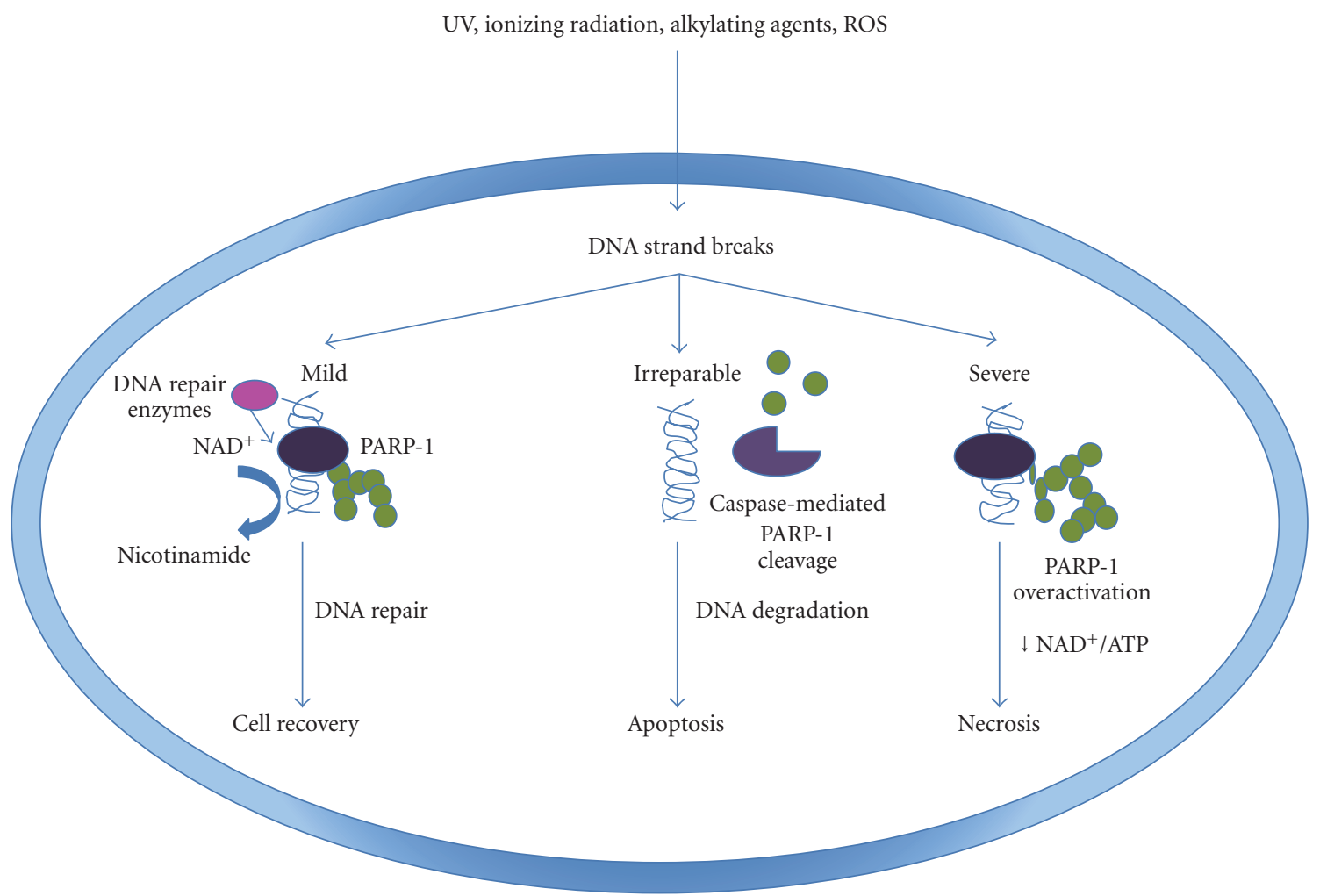

FIGURE 3: PARP-1 and cellular responses to DNA damage. The intensity of DNA damage determines cellular pathways: survival, apoptosis, or necrosis. In the case of mild DNA damage, poly(ADP-ribosylation) enhances DNA repair and thus cell survival. When the damage is beyond repair, PARP-1 facilitates apoptosis, preventing ATP depletion and DNA repair through PARP-1 caspase-mediated cleavage. Severe DNA damage leads to PARP-1 overactivation, cellular energy depletion, and necrotic cell death. Figure is adapted from Virág and Szabó, in 2002 [70].

substantially reduced sensitivity to the carcinogenic effect of DMBA and TPA on the skin [136]. In PARP-1 null (parp-1 ${ }^{-/-}$) mice, the development of skin papillomas induced by DMBA and TPA was significantly delayed and reduced in numbers compared to control (parp- $1^{+/+}$) mice. PARP-1 inhibition in mice with 3,4-dihydro-5-[4-(1piperidinyl)butoxyl]-1(2H)-isoquinoinone (DPQ) also had the same effect [142]. PARP-1 inhibition with nicotinamide and benzamides was also shown to inhibit NF- $\kappa \mathrm{B}$ in vitro and suppress lipopolysaccharide-induced TNF- $\alpha$ production in mice [143]. Indirect inhibition of NF- $\kappa \mathrm{B}$ by elimination or inhibition of PARP-1 may prevent activation of $\kappa \mathrm{B}$ target genes, leading to suppression of inflammation and expression of genes associated with tumor progression [136]. Although PARP-1 knockout mice as mentioned previously have increased genomic instability in response to alkylating agents and ionizing radiation [81-83] and were more recently shown to be more sensitive to nitrosamine- [85] and azoxymethane-induced cancers [144], it is thought that this controversy can be explained by the unique environmental and intrinsic factors involved in tumorigenesis of differing genotoxic agents and organs [136].

PARP-1 inhibition by DPQ or by genetic deletion of PARP-1 in mice was also found to normalize or downregulate some upregulated genes in DMBA/TPA-treated skin, including several tumor-associated genes in mouse and human and genes involved in oxidative stress, inflammation, and the immune response. Of particular importance is the absence of induction of Hif (Hypoxia inducible factor) $-1 \alpha$ in the PARP1 deficient and DPQ-treated murine skin [142]. The transcription factor Hif- $1 \alpha$ promotes the adaptation of tumour cells to hypoxia, including angiogenesis, vasodilation, glucose transport, and anaerobic metabolism [145]. It was also noted that in the tumours of DPQ-treated mice, there were increased apoptotic cells, suggesting that inhibition of Hif$1 \alpha$ may contribute to tumour death through failure of these cells to adapt to hypoxia [142]. In our research group, topical nicotinamide was found to normalize subsets of apoptosis, energy metabolism, and immune function-related genes that are downregulated by UVR in human skin [63]. Low dose of ssUV was shown in this study to downregulate apoptotic genes BCL2, TP53, IGF1R, PRKCA, and AKT1, which are also involved in the regulation of telomerase activity, and thought to play important roles in the initiation of skin carcinogenesis $[63,146]$. Normalisation of these subsets of genes by nicotinamide suggests its involvement in apoptosis and early events in skin carcinogenesis. The downregulation of genes for energy production in ssUVtreated skin supports evidence for the cellular energy decline known to be induced by UVR [90]. As previously mentioned, DNA repair requires ATP [87], and an adequate $\mathrm{NAD}^{+}$ level is critical in maintaining the genomic integrity of skin 
cells during UV radiation [90]. Consistent with its role as an $\mathrm{NAD}^{+}$and ATP precursor, nicotinamide protects the cell from UVR-induced energy depletion. Nicotinamide also normalized ssUV downregulation of TP53 genes. p53 is a key regulator of cell cycle arrest and apoptosis in response to DNA damage [147]. In response to genotoxic stress, p53 is stabilized and activated by posttranslational modifications, including poly(ADP-ribosyl)ation, phosphorylation, and acetylation [148, 149]. Niacin deficiency in rats [104] and nicotinamide depletion in cultured cells derived from breast, lung, and skin cells [23] caused decreased expression of the tumor suppressor protein, p53. PARP-1 inhibition has been shown to decrease basal p53 levels and impairs p53 stabilization after DNA damage [150]. In addition, PARP-1 deficient cell lines exhibit a significant reduction in both baseline p53 expression and its activity compared to normal wild type cells [150]. Diminished p53 function is highly associated with malignancy in breast, lungs, and skin [151]. Nicotinamide prevented UV-induced downregulation of p53, suggesting its mode of protection from genotoxic effect of UVR. The effect of nicotinamide on p53 regulation has also been reported to be independent of PARP [152].

\section{Conclusion}

Nicotinamide, which is the dietary precursor for $\mathrm{NAD}^{+}$, provides a substrate for PARP-1 activity. The activation of nuclear enzyme PARP-1 by DNA strand breaks during cellular genotoxic stress responses leads to complex signaling pathway that can enhance DNA repair, result in apoptotic cell death, or cause cellular energy loss leading to necrotic cell death. In vivo and in vitro studies showed that $\mathrm{NAD}^{+}$ content of the cells influences responses to DNA damaging agents. $\mathrm{NAD}^{+}$depletion impairs ADP-ribose polymer metabolism and increases genomic instability in the face of genotoxic and oxidative stress challenges. Nicotinamide deficiency in humans may also contribute to increased frequency of gastrointestinal cancers in certain populations although other micronutrient deficiencies are likely to be involved as well. Nicotinamide supplementation in animal models has opposing effect on carcinogenesis, depending on the type of carcinogens and target organs. Nicotinamide protected against UV-induced immunosuppression in mice and humans and UV-induced carcinogenesis in mice. Limited study in humans indicates that skin $\mathrm{NAD}^{+}$ content is an important determinant of malignant phenotype. Thus, nicotinamide supplementation may influence the progression of premalignant actinic keratoses to malignant squamous cell cancers. PARP-1 plays a key role in regulation of genes involved in inflammation, apoptosis, and cellular differentiation. While PARP-1 inhibition could impair its role in DNA repair, PARP-1 overactivation is detrimental to the cells by depleting its substrate $\mathrm{NAD}^{+}$, which leads to cellular energy crisis and necrotic cell death. In various murine models, PARP-1 inhibition was shown to favor apoptotic cell death, reduce inflammatory response, and reduce genomic sensitivity to various carcinogens. However, extrapolation of these data to human, particularly when physiological regimes involved in human carcinogenesis, should be done cautiously. Further studies are needed to determine the effect of high-dose nicotinamide on in vivo carcinogenesis and genomic stability of the cancer cells and the surrounding normal cells.

\section{Abbreviations}

BOB N-nitrosobis(2-oxopropylamine)

DEN: diethylnitrosamine

DMBA: 9,10-dimethyl-12-benzanthracene

DMS: dimethyl sulphate

DTH: delayed-type hypersensitivity

ETO: etoposide; FBS, fetal bovine serum

$\mathrm{MN}$ : micronuclei

MNNG: N-methyl-N'-nitro-N-nitrosoguanidine

$\mathrm{NAD}^{+}$: nicotinamide adenine dinucleotide

PARP: poly-ADP-ribose polymerase

ROS: reactive oxygen species

SCE: sister chromatid exchange

ssUV: solar-simulated ultraviolet

TPA: 12-O-tetradecanoylphorbol-13-acetate

UDS: unscheduled DNA synthesis

UVR: ultraviolet radiation.

\section{References}

[1] R. A. Jacob and M. E. Swendseid, "Niacin," in Present Knowledge in Nutrition, E. E. Ziegler and L. J. Filer, Eds., pp. 184-190, ILSI Press, Washington, DC, USA, 1996.

[2] C. A. Benavente, M. K. Jacobson, and E. L. Jacobson, "NAD in skin: therapeutic approaches for niacin," Current Pharmaceutical Design, vol. 15, no. 1, pp. 29-38, 2009.

[3] K. Karthikeyan and D. M. Thappa, "Pellagra and skin," International Journal of Dermatology, vol. 41, no. 8, pp. 476481, 2002.

[4] "Nutrient Reference Values for Australian and New Zealand, including recommended dietary intake," pp.1-329, National Health and Medical Research Council publication, Canberra, Australia, 2006.

[5] T. M. Jackson, J. M. Rawling, B. D. Roebuck, and J. B. Kirkland, "Large supplements of nicotinic acid and nicotinamide increase tissue NAD+ and poly(ADP-ribose) levels but do not affect diethylnitrosamine-induced altered hepatic foci in Fischer-344 rats," Journal of Nutrition, vol. 125, no. 6, pp. 1455-1461, 1995.

[6] E. L. Jacobson, A. J. Dame, J. S. Pyrek, and M. K. Jacobson, "Evaluating the role of niacin in human carcinogenesis," Biochimie, vol. 77, no. 5, pp. 394-398, 1995.

[7] Cosmetic Ingredient Review (CIR) Expert Panel, "Final report of the safety assessment of niacinamide and niacin," International Journal of Toxicology, vol. 24, pp. 1-31, 2005.

[8] J. Denekamp and J. F. Fowler, "ARCON_current status: summary of a workshop on preclinical and clinical studies," Acta Oncologica, vol. 36, no. 5, pp. 517-525, 1997.

[9] S. L. Winter and J. L. Boyer, "Hepatic toxicity from large doses of vitamin-B3 (Nicotinamide)," New England Journal of Medicine, vol. 289, no. 22, pp. 1180-1182, 1973.

[10] J. H. A. M. Kaanders, M. R. L. Stratford, J. Liefers et al., "Administration of nicotinamide during a five- to sevenweek course of radiotherapy: pharmacokinetics, tolerance, 
and compliance," Radiotherapy and Oncology, vol. 43, no. 1, pp. 67-73, 1997.

[11] R. E. Ranchoff and K. Tomecki, "Niacin or niacinamide? Nicotinic acid or nicotinamide? What is the difference?" Journal of the American Academy of Dermatology, vol. 15, no. 1, pp. 116-117, 1986.

[12] M. L. Meyer-Ficca, R. G. Meyer, E. L. Jacobson, and M. K. Jacobson, "Poly(ADP-ribose) polymerases: managing genome stability," International Journal of Biochemistry and Cell Biology, vol. 37, no. 5, pp. 920-926, 2005.

[13] W. M. Hendricks, "Pellagra and pellagralike dermatoses: etiology, differential diagnosis, dermatopathology, and treatment," Seminars in Dermatology, vol. 10, no. 4, pp. 282-292, 1991.

[14] P. Chambon, J. D. Weill, and P. Mandel, "Nicotinamide mononucleotide activation of a new DNA-dependent polyadenylic acid synthesizing nuclear enzyme," Biochemical and Biophysical Research Communications, vol. 11, no. 1, pp. 39-43, 1963.

[15] F. J. Oliver, J. Menissier-de Murcia, and G. De Murcia, "Poly(ADP-Ribose) polymerase in the cellular response to DNA damage, apoptosis, and disease," American Journal of Human Genetics, vol. 64, no. 5, pp. 1282-1288, 1999.

[16] J. P. Kamat and T. P. A. Devasagayam, "Methylene blue plus light-induced lipid peroxidation in rat liver microsomes: inhibition by nicotinamide (vitamin B3) and other antioxidants," Chemico-Biological Interactions, vol. 99, no. 1-3, pp. 1-16, 1996.

[17] K. Yamada, K. Nonaka, T. Hanafusa, A. Miyazaki, H. Toyoshima, and S. Tarui, "Preventative and therapeutic effects of large-dose nicotinamide injections on diabetes associated with insulitis-an observation in non-obese diabetic (NOD) mice," Diabetes, vol. 31, no. 9, pp. 749-753, 1982.

[18] D. M. Abdallah, "Nicotinamide alleviates indomethacininduced gastric ulcers: a novel antiulcer agent," European Journal of Pharmacology, vol. 627, no. 1-3, pp. 276-280, 2010.

[19] A. M. Vincent, M. J. Stevens, C. Backus, L. L. Mclean, and E. L. Feldman, "Cell culture modeling to test therapies against hyperglycemia-mediated oxidative stress and injury," Antioxidants and Redox Signaling, vol. 7, no. 11-12, pp. 14941506, 2005.

[20] G. L. Wilson, N. J. Patton, and J. M. McCord, "Mechanisms of streptozotocin- and alloxan-induced damage in the rat Bcells," Diabetologia, vol. 27, no. 6, pp. 587-591, 1984.

[21] C. Q. Vu, D. L. Coyle, H. H. Tai, E. L. Jacobson, and M. K. Jacobson, "Intramolecular ADP-ribose transfer reactions and calcium signalling," in ADP-Ribosylation in Animal Tissue: Structure, Function, and Biology of Mono-ADPRibosyltransferases and Related Enzymes, F. Haag and F. KochNolte, Eds., pp. 381-388, Plenum Press, New York, NY, USA, 1997.

[22] C. O. Vu, D. L. Coyle, E. L. Jacobson, and M. K. Jacobson, "Intracellular signaling by cylic ADP-Ribose in oxidative cell injury," FASEB Journal, vol. 11, no. 9, p. 1522, 1997.

[23] E. L. Jacobson, W. M. Shieh, and A. C. Huang, "Mapping the role of NAD metabolism in prevention and treatment of carcinogenesis," Molecular and Cellular Biochemistry, vol. 193, no. 1-2, pp. 69-74, 1999.

[24] W. J. Blot, J.-Y. Li, P. R. Taylor et al., "Nutrition intervention trials in Linxian, China. Supplementation with specific vita$\mathrm{min} /$ mineral combinations, cancer incidence, and diseasespecific mortality in the general population," Journal of the
National Cancer Institute, vol. 85, no. 18, pp. 1483-1492, 1993.

[25] S. Franceschi, E. Bidoli, A. E. Baron, and C. La Vecchia, "Maize and risk of cancers of the oral cavity, pharynx, and esophagus in Northeastern Italy," Journal of the National Cancer Institute, vol. 82, no. 17, pp. 1407-1411, 1990.

[26] E. Negri, S. Franceschi, C. Bosetti et al., "Selected micronutrients and oral and pharyngeal cancer," International Journal of Cancer, vol. 86, no. 1, pp. 122-127, 2000.

[27] F. Siassi, Z. Pouransari, and P. Ghadirian, "Nutrient intake and esophageal cancer in the caspian littoral of Iran: a casecontrol study," Cancer Detection and Prevention, vol. 24, no. 3, pp. 295-303, 2000.

[28] G. C. Kabat, A. B. Miller, M. Jain, and T. E. Rohan, "Dietary intake of selected B vitamins in relation to risk of major cancers in women," British Journal of Cancer, vol. 99, no. 5, pp. 816-821, 2008.

[29] L. B. Zablotska, Y. Chen, J. H. Graziano et al., "Protective effects of B vitamins and antioxidants on the risk of arsenicrelated skin lesions in Bangladesh," Environmental Health Perspectives, vol. 116, no. 8, pp. 1056-1062, 2008.

[30] C. Pelucchi, I. Tramacere, P. Bertuccio, A. Tavani, E. Negri, and C. La Vecchia, "Dietary intake of selected micronutrients and gastric cancer risk: an Italian case-control study," Annals of Oncology, vol. 20, no. 1, pp. 160-165, 2009.

[31] C.-X. Qu, F. Kamangar, J.-H. Fan et al., "Chemoprevention of primary liver cancer: a randomized, double-blind trial in Linxian, China," Journal of the National Cancer Institute, vol. 99, no. 16, pp. 1240-1247, 2007.

[32] C. Bosetti, L. Scotti, L. Dal Maso et al., "Micronutrients and the risk of renal cell cancer: a case-control study from Italy," International Journal of Cancer, vol. 120, no. 4, pp. 892-896, 2007.

[33] E. L. Jacobson, "Niacin deficiency and cancer in women," Journal of the American College of Nutrition, vol. 12, no. 4, pp. 412-416, 1993.

[34] R. I. Inculet, J. A. Norton, and G. E. Nichoalds, "Watersoluble vitamins in cancer patients on parenteral nutrition: a prospective study," Journal of Parenteral and Enteral Nutrition, vol. 11, no. 3, pp. 243-249, 1987.

[35] S. Dreizen, K. B. McCredie, M. J. Keating, and B. S. Andersson, "Nutritional deficiencies in patients receiving cancer chemotherapy," Postgraduate Medicine, vol. 87, no. 1, pp. 163-170, 1990.

[36] H. P. Stevens, L. S. Ostlere, R. H. J. Begent, J. S. Dooley, and M. H. A. Rustin, "Pellagra secondary to 5-fluorouracil," British Journal of Dermatology, vol. 128, no. 5, pp. 578-580, 1993.

[37] C. W. Op Het Veld, S. Van Hees-Stuivenberg, A. A. Van Zeeland, and J. G. Jansen, "Effect of nucleotide excision repair on hprt gene mutations in rodent cells exposed to DNA ethylating agents," Mutagenesis, vol. 12, no. 6, pp. 417424, 1997.

[38] C. A. Felix, "Secondary leukemias induced by topoisomerasetargeted drugs," Biochimica et Biophysica Acta, vol. 1400, no. 1-3, pp. 233-255, 1998.

[39] J. B. Kirkland, "Niacin and carcinogenesis," Nutrition and Cancer, vol. 46, no. 2, pp. 110-118, 2003.

[40] B. Toth, "Lack of carcinogenicity of nicotinamide and isonicotinamide following lifelong administration to mice," Oncology, vol. 40, no. 1, pp. 72-75, 1983.

[41] F. A. French, "The influence of nutritional factors on pulmonary adenomas in mice," in Inorganic and Nutritional 
Aspects of Cancer, G. N. Schrauzer, Ed., Plenum Press, New York, NY, USA, 1978.

[42] H. Gotoh, T. Nomura, H. Nakajima, C. Hasegawa, and Y. Sakamoto, "Inhibiting effects of nicotinamide on urethaneinduced malformations and tumors in mice," Mutation Research, vol. 199, no. 1, pp. 55-63, 1988.

[43] A.-P. Bartleman, R. Jacobs, and J. B. Kirkland, "Niacin supplementation decreases the incidence of alkylation-induced nonlymphocytic leukemia in long-evans rats," Nutrition and Cancer, vol. 60, no. 2, pp. 251-258, 2008.

[44] H. Gotoh, T. Nomura, and C. Hasegawa, "Growth-inhibition of transplanted murine-breast cancer by nicotinamide in C3H/HEJ mice," Cancer Research Therapy and Control, vol. 3, no. 2, pp. 121-126, 1993.

[45] M. R. Horsman, A. A. Khalil, D. J. Chaplin, and J. Overgaard, "The ability of nicotinamide to inhibit the growth of a $\mathrm{C} 3 \mathrm{H}$ mouse mammary carcinoma," Acta Oncologica, vol. 34, no. 3, pp. 443-446, 1995.

[46] R. Schoental, "The role of nicotinamide and of certain other modifying factors in diethylnitrosamine carcinogenesis: fusaria mycotoxins and spontaneous tumors in animals and man," Cancer, vol. 40, no. 4, pp. 1833-1840, 1977.

[47] M. R. Rosenberg, D. L. Novicki, and R. L. Jirtle, "Promoting effect of nicotinamide on the development of renal tubular cell tumors in rats initiated with diethylnitrosamine," Cancer Research, vol. 45, no. 2, pp. 809-814, 1985.

[48] N. Rakieten, B. S. Gordon, A. Beaty, D. A. Cooney, R. D. Davis, and P. S. Schein, "Pancreatic islet cell tumors produced by the combined action of streptozotocin and nicotinamide," Proceedings of the Society for Experimental Biology and Medicine, vol. 137, no. 1, pp. 280-283, 1971.

[49] N. Rakieten, B. S. Gordon, and A. Beaty, "Modification of renal tumorigenic effect of streptozotocin by nicotinamide: spontaneous reversibility of streptozotocin diabetes," Proceedings of the Society for Experimental Biology and Medicine, vol. 151, no. 2, pp. 356-361, 1976.

[50] R. Schoental, "Pancreatic islet cell and other tumors in rats given heliotrine, a monoester pyrrolizidine alkaloid, and nicotinamide," Cancer Research, vol. 35, no. 8, pp. 2020-2024, 1975.

[51] V. Burkart, Z.-Q. Wang, J. Radons et al., "Mice lacking the poly(ADP-ribose) polymerase gene are resistant to pancreatic beta-cell destruction and diabetes development induced by streptozocin," Nature Medicine, vol. 5, no. 3, pp. 314-319, 1999.

[52] H. L. Gensler, "Prevention of photoimmunosuppression and photocarcinogenesis by topical nicotinamide," Nutrition and Cancer, vol. 29, no. 2, pp. 157-162, 1997.

[53] H. L. Gensler, T. Williams, A. C. Huang, and E. L. Jacobson, "Oral niacin prevents photocarcinogenesis and photoimmunosuppression in mice," Nutrition and Cancer, vol. 34, no. 1, pp. 36-41, 1999.

[54] A. Ludwig, M. Dietel, G. Schafer, K. Muller, and H. Hilz, "Nicotinamide and nicotinamide analogues as antitumor promoters in mouse skin," Cancer Research, vol. 50, no. 8, pp. 2470-2475, 1990.

[55] F. J. C. Roe, "Effect of massive doses of riboflavin, and other vitamins of the B group, on skin carcinogenesis in mice," British Journal of Cancer, vol. 16, pp. 252-257, 1964.

[56] A. M. Pamukcu, U. Milli, and G. T. Bryan, "Protective effect of nicotinamide on bracken fern inducec carcinogenecity in rats," Nutrition and Cancer, vol. 3, p. 86, 1981.

[57] P. M. Pour and T. Lawson, "Modification of pancreatic carcinogenesis in the hamster model. XV. Preventive effect of nicotinamide," Journal of the National Cancer Institute, vol. 73, no. 3, pp. 767-770, 1984.

[58] F. J. Moloney, H. Comber, P. O’Lorcain, P. O’Kelly, P. J. Conlon, and G. M. Murphy, "A population-based study of skin cancer incidence and prevalence in renal transplant recipients," British Journal of Dermatology, vol. 154, no. 3, pp. 498-504, 2006.

[59] G. M. Halliday and H. Honigsmann, "Sunscreens, photoimmunosuppression, and photoaging," in Clinical Guide to Sunscreeens and Photoprotection, H. W. Lim and Z. D. Draelos, Eds., pp. 101-116, Informa Healthcare USA, Inc, New York, NY, USA, 2009.

[60] G. M. Halliday, R. Bestak, K. S. Yuen, L. L. Cavanagh, and R. S. C. Barnetson, "UVA-induced immunosuppression," Mutation Research, vol. 422, no. 1, pp. 139-145, 1998.

[61] D. L. Damian, R. S. C. Barnetson, and G. M. Halliday, "Low-dose UVA and UVB have different time courses for suppression of contact hypersensitivity to a recall antigen in humans," Journal of Investigative Dermatology, vol. 112, no. 6, pp. 939-944, 1999.

[62] L. A. Applegate, R. D. Ley, J. Alcalay, and M. L. Kripke, "Identification of the molecular target for the suppression of contact hypersensitivity by ultraviolet radiation," Journal of Experimental Medicine, vol. 170, no. 4, pp. 1117-1131, 1989.

[63] D. L. Damian, C. R. S. Patterson, M. Stapelberg, J. Park, R. S. C. Barnetson, and G. M. Halliday, "UV radiation-induced immunosuppression is greater in men and prevented by topical nicotinamide," Journal of Investigative Dermatology, vol. 128, no. 2, pp. 447-454, 2008.

[64] E. Yiasemides, G. Sivapirabu, G. M. Halliday, J. Park, and D. L. Damian, "Oral nicotinamide protects against ultraviolet radiation-induced immunosuppression in humans," Carcinogenesis, vol. 30, no. 1, pp. 101-105, 2009.

[65] D. L. Damian and G. M. Halliday, "Measurement of ultraviolet radiation-induced suppression of recall contact and delayed-type hypersensitivity in humans," Methods, vol. 28, no. 1, pp. 34-45, 2002.

[66] G. Sivapirabu, E. Yiasemides, G. M. Halliday, J. Park, and D. L. Damian, "Topical nicotinamide modulates cellular energy metabolism and provides broad-spectrum protection against ultraviolet radiation-induced immunosuppression in humans," British Journal of Dermatology, vol. 161, no. 6, pp. 1357-1364, 2009.

[67] G. De Murcia, V. Schreiber, M. Molinete et al., "Structure and function of poly(ADP-ribose) polymerase," Molecular and Cellular Biochemistry, vol. 138, no. 1-2, pp. 15-24, 1994.

[68] G. De Murcia and J. Menissier-de Murcia, "Poly(ADP-ribose) polymerase: a molecular nick-sensor," Trends in Biochemical Sciences, vol. 19, no. 4, pp. 172-176, 1994.

[69] S. Shall and G. De Murcia, "Poly(ADP-ribose) polymerase1: what have we learned from the deficient mouse model?" Mutation Research, vol. 460, no. 1, pp. 1-15, 2000.

[70] L. Virág and C. Szabó, "The therapeutic potential of poly(ADP-ribose) polymerase inhibitors," Pharmacological Reviews, vol. 54, no. 3, pp. 375-429, 2002.

[71] G. J. Hageman and R. H. Stierum, "Niacin, poly(ADP-ribose) polymerase-1 and genomic stability," Mutation Research, vol. 475, no. 1-2, pp. 45-56, 2001.

[72] M. Y. Kim, S. Mauro, N. Gévry, J. T. Lis, and W. L. Kraus, "NAD ${ }^{+}$-dependent modulation of chromatin structure and transcription by nucleosome binding properties of PARP-1," Cell, vol. 119, no. 6, pp. 803-814, 2004. 
[73] S. D. Skaper, "Poly(ADP-ribose) polymerase-1 in acute neuronal death and inflammation - a strategy for neuroprotection," in Neuroprotective Agents, W. Slikkerandr, J. Andrews, and B. Trembly, Eds., pp. 217-228, The New York Academy of Sciences, New York, NY, USA, 2003.

[74] R. H. Stierum, M. H. M. Van Herwijnen, G. J. Hageman, and J. C. S. Kleinjans, "Increased poly(ADP-ribose) polymerase activity during repair of $( \pm)$-anti-benzo[a]pyrene diolepoxide-induced DNA damage in human peripheral blood lymphocytes in vitro," Carcinogenesis, vol. 15 , no. 4 , pp. 745-751, 1994.

[75] C. Trucco, F. J. Oliver, G. De Murcia, and J. Menissier-de Murcia, "DNA repair defect in poly(ADP-ribose) polymerasedeficient cell lines," Nucleic Acids Research, vol. 26, no. 11, pp. 2644-2649, 1998.

[76] M. Molinete, W. Vermeulen, A. Burkle, et al., "Overproduction of the poly(ADP-ribose)polymerase DNA-binding domain blocks alkylation-induced DNA-repair synthesis in mammalian-cells," Embo Journal, vol. 12, no. 5, pp. 21092117, 1993.

[77] R. Ding and M. Smulson, "Depletion of nuclear poly(ADPribose)polymerase by antisense RNA expression-influences on genomic stability, chromatin organization and DNArepair," Faseb Journal, vol. 8, no. 7, p. A1409, 1994.

[78] F. Dantzer, H. P. Nasheuer, J. L. Vonesch, G. de Murcia, and J. Menissier-de Murcia, "Functional association of poly(ADPribose) polymerase with DNA polymerase alpha-primase complex: a link between DNA strand break detection and DNA replication," Nucleic Acids Research, vol. 26, no. 8, pp. 1891-1898, 1998.

[79] M. S. Satoh, G. G. Poirier, and T. Lindahl, "Dual function for poly(ADP-ribose) synthesis in response to DNA strand breakage," Biochemistry, vol. 33, no. 23, pp. 7099-7106, 1994.

[80] S. Chatterjee, S. J. Berger, and N. A. Berger, "Poly(ADPribose) polymerase: a guardian of the genome that facilitates DNA repair by protecting against DNA recombination," Molecular and Cellular Biochemistry, vol. 193, no. 1-2, pp. 2330, 1999.

[81] C. Trucco, V. Rolli, F. J. Oliver et al., "A dual approach in the study of poly (ADP-ribose) polymerase: in vitro random mutagenesis and generation of deficient mice," Molecular and Cellular Biochemistry, vol. 193, no. 1-2, pp. 53-60, 1999.

[82] M. Masutani, T. Nozaki, K. Nakamoto et al., "The response of Parp knockout mice against DNA damaging agents," Mutation Research, vol. 462, no. 2-3, pp. 159-166, 2000.

[83] Z.-Q. Wang, L. Stingl, C. Morrison et al., "PARP is important for genomic stability but dispensable in apoptosis," Genes and Development, vol. 11, no. 18, pp. 2347-2358, 1997.

[84] J. Menissier-de Murcia, C. Niedergang, C. Trucco et al., "Requirement of poly(ADP-ribose) polymerase in recovery from DNA damage in mice and in cells," Proceedings of the National Academy of Sciences of the United States of America, vol. 94, no. 14, pp. 7303-7307, 1997.

[85] M. Tsutsumi, M. Masutani, T. Nozaki et al., "Increased susceptibility of poly(ADP-ribose) polymerase-1 knockout mice to nitrosamine carcinogenicity," Carcinogenesis, vol. 22, no. 1, pp. 1-3, 2001.

[86] F. D. Di Fagagna, M. P. Hande, W.-M. Tong, P. M. Lansdorp, Z.-Q. Wang, and S. P. Jackson, "Functions of poly(ADPribose) polymerase in controlling telomere length and chromosomal stability," Nature Genetics, vol. 23, no. 1, pp. 76-80, 1999.
[87] M. A. Osley, T. Tsukuda, and J. A. Nickoloff, "ATP-dependent chromatin remodeling factors and DNA damage repair," Mutation Research, vol. 618, no. 1-2, pp. 65-80, 2007.

[88] F. Li, Z. Z. Chong, and K. Maiese, "Cell life versus cell longevity: the mysteries surrounding the $\mathrm{NAD}^{+}$precursor nicotinamide," Current Medicinal Chemistry, vol. 13, no. 8, pp. 883-895, 2006.

[89] B. W. Durkacz, O. Omidiji, D. A. Gray, and S. Shall, "(ADPribose)n participates in DNA excision repair," Nature, vol. 283, no. 5747, pp. 593-596, 1980.

[90] E. L. Jacobson, P. U. Giacomoni, M. J. Roberts, G. T. Wondrak, and M. K. Jacobson, "Optimizing the energy status of skin cells during solar radiation," Journal of Photochemistry and Photobiology B, vol. 63, no. 1-3, pp. 141-147, 2001.

[91] C. A. Benavente and E. L. Jacobson, "Niacin restriction upregulates NADPH oxidase and reactive oxygen species (ROS) in human keratinocytes," Free Radical Biology and Medicine, vol. 44, no. 4, pp. 527-537, 2008.

[92] A. B. Weitberg, "Effect of nicotinic acid supplementation in vivo on oxygen radical-induced genetic damage in human lymphocytes," Mutation Research, vol. 216, no. 4, pp. 197201, 1989.

[93] N. A. Berger and G. W. Sikorski, "Nicotinamide stimulates repair of DNA damage in human lymphocytes," Biochemical and Biophysical Research Communications, vol. 95, no. 1, pp. 67-72, 1980.

[94] J. L. Sims, S. J. Berger, and N. A. Berger, "Effects of nicotinamide on NAD and poly(ADP-ribose) metabolism in DNAdamaged human lymphocytes," Journal of Supramolecular and Cellular Biochemistry, vol. 16, no. 3, pp. 281-288, 1981.

[95] E. Kjellen, G. G. Jonsson, R. W. Pero, and P.-I. Christensson, "Effects of hyperthermia and nicotinamide on DNA repair synthesis, ADP-ribosyl transferase activity, NAD+ and ATP pools, and cytotoxicity in $\gamma$-irradiated human mononuclear leukocytes," International Journal of Radiation Biology, vol. 49, no. 1, pp. 151-162, 1986.

[96] J. E. Cleaver and J. E. Trosko, "Defective stage of DNA repair in a human disease, xeroderma pigmentosum," Radiation Research, vol. 39, no. 2, p. 471, 1969.

[97] M. Miwa, M. Kanai, T. Kondo, H. Hoshino, K. Ishihara, and T. Sugimura, "Inhibitors of poly(ADP-ribose)polymerase enhance unscheduled DNA-synthesis in human peripheral lymphocytes," Biochemical and Biophysical Research Communications, vol. 100, no. 1, pp. 463-470, 1981.

[98] K. Tang, H. Sham, E. Hui, and J. B. Kirkland, "Niacin deficiency causes oxidative stress in rat bone marrow cells but not through decreased NADPH or glutathione status," Journal of Nutritional Biochemistry, vol. 19, no. 11, pp. 746753, 2008.

[99] V. O. Melnikova and H. N. Ananthaswamy, "Cellular and molecular events leading to the development of skin cancer," Mutation Research, vol. 571, no. 1-2, pp. 91-106, 2005.

[100] A. Svobodova, D. Walterova, and J. Vostalova, "Ultraviolet light induced alteration to the skin," Biomedical papers of the Medical Faculty of the University Palacký, Olomouc, Czechoslovakia, vol. 150, no. 1, pp. 25-38, 2006.

[101] G. M. Halliday, "Inflammation, gene mutation and photoimmunosuppression in response to UVR-induced oxidative damage contributes to photocarcinogenesis," Mutation Research, vol. 571, no. 1-2, pp. 107-120, 2005.

[102] A. C. Boyonoski, J. C. Spronck, L. M. Gallacher et al., "Niacin deficiency decreases bone marrow poly(ADP-ribose) and the latency of ethylnitrosourea-induced carcinogenesis in rats," Journal of Nutrition, vol. 132, no. 1, pp. 108-114, 2002. 
[103] J. C. Spronck and J. B. Kirkland, "Niacin deficiency increases spontaneous and etoposide-induced chromosomal instability in rat bone marrow cells in vivo," Mutation Research, vol. 508, no. 1-2, pp. 83-97, 2002.

[104] J. C. Spronck, J. L. Nickerson, and J. B. Kirkland, "Niacin deficiency alters p53 expression and impairs etoposideinduced cell cycle arrest and apoptosis in rat bone marrow cells," Nutrition and Cancer, vol. 57, no. 1, pp. 88-99, 2007.

[105] L. M. Kostecki, M. Thomas, G. Linford et al., "Niacin deficiency delays DNA excision repair and increases spontaneous and nitrosourea-induced chromosomal instability in rat bone marrow," Mutation Research, vol. 625, no. 1-2, pp. 50-61, 2007.

[106] J. B. Kirkland, "Niacin status and treatment-related leukemogenesis," Molecular Cancer Therapeutics, vol. 8, no. 4, pp. 725-732, 2009.

[107] V. Rolli, R. Armin, A. Augustin, G. Schulz, J. Menissier-de Murcia, and G. de Murcia, Poly ADP-Ribosylation Reactions: From DNA Damage and Stress Signalling to Cell Death, Oxford University Press, Oxford, UK, 2000.

[108] G. E. N. Kass, J. E. Eriksson, M. Weis, S. Orrenius, and S. C. Chow, "Chromatin condensation during apoptosis requires ATP," Biochemical Journal, vol. 318, no. 3, pp. 749-752, 1996.

[109] C. Richter, M. Schweizer, A. Cossarizza, and C. Franceschi, "Control of apoptosis by the cellular ATP level," FEBS Letters, vol. 378, no. 2, pp. 107-110, 1996.

[110] C. Stefanelli, F. Bonavita, I. Stanic' et al., “ATP depletion inhibits glucocorticoid-induced thymocyte apoptosis," Biochemical Journal, vol. 322, no. 3, pp. 909-917, 1997.

[111] D. Ferrari, A. Stepczynska, M. Los, S. Wesselborg, and K. Schulze-Osthoff, "Differential regulation and ATP requirement for caspase- 8 and caspase-3 activation during CD95and anticancer drug-induced apoptosis," Journal of Experimental Medicine, vol. 188, no. 5, pp. 979-984, 1998.

[112] S. D. Park, C. G. Kim, and M. G. Kim, "Inhibitors of poly(ADP-ribose) polymerase enhance DNA strand breaks, excision repair, and sister chromatid exchanges induced by alkylating agents," Environmental Mutagenesis, vol. 5, no. 4, pp. 515-525, 1983.

[113] R. W. Pero, B. Axelsson, D. Siemann, D. Chaplin, and G. Dougherty, "Newly discovered anti-inflammatory properties of the benzamides and nicotinamides," Molecular and Cellular Biochemistry, vol. 193, no. 1-2, pp. 119-125, 1999.

[114] E. Riklis, R. Kol, and R. Marko, "Trends and developments in radioprotection: the effect of nicotinamide on DNA repair," International Journal of Radiation Biology, vol. 57, no. 4, pp. 699-708, 1990.

[115] H. Zheng and P. L. Olive, "Reduction of tumor hypoxia and inhibition of DNA repair by nicotinamide after irradiation of SCCVII murine tumors and normal tissues," Cancer Research, vol. 56, no. 12, pp. 2801-2808, 1996.

[116] F. R. Althaus, S. D. Lawrence, G. L. Sattler, and H. C. Pitot, "The effect of nicotinamide on unscheduled DNA synthesis in cultured hepatocytes," Biochemical and Biophysical Research Communications, vol. 95, no. 3, pp. 1063-1070, 1980.

[117] A. Oikawa, H. Tohda, M. Kanai, M. Miwa, and T. Sugimura, "Inhibitors of poly(adenosine diphosphate ribose) polymerase induce sister chromatid exhanges," Biochemical and Biophysical Research Communications, vol. 97, no. 4, pp. 1311-1316, 1980.
[118] T. Utakoji, K. Hosoda, K. Umezawa, and M. Sawamura, "Induction of sister chromatid exchanges by nicotinamide in chinese-hamster lung fibroblasts and humanlymphoblastoid cells," Biochemical and Biophysical Research Communications, vol. 90, no. 4, pp. 1147-1152, 1979.

[119] J. B. Kirkland, "Niacin status, NAD distribution and ADPribose metabolism," Current Pharmaceutical Design, vol. 15, no. 1, pp. 3-11, 2009.

[120] P. W. Rankin, E. L. Jacobson, R. C. Benjamin, J. Moss, and M. K. Jacobson, "Quantitative studies of inhibitors of ADP-ribosylation invitro and invivo," Journal of Biological Chemistry, vol. 264, no. 8, pp. 4312-4317, 1989.

[121] R. L. Thies and A. P. Autor, "Reactive oxygen injury to cultured pulmonary artery endothelial cells: mediation by poly(ADP-ribose) polymerase activation causing NAD depletion and altered energy balance," Archives of Biochemistry and Biophysics, vol. 286, no. 2, pp. 353-363, 1991.

[122] D. G. Hoyt and J. S. Lazo, "NAD depletion after in vitro exposure of murine lung slices to bleomycin," Biochemical Pharmacology, vol. 46, no. 10, pp. 1819-1824, 1993.

[123] B. Farkas, M. Magyarlaki, B. Csete et al., "Reduction of acute photodamage in skin by topical application of a novel PARP inhibitor," Biochemical Pharmacology, vol. 63, no. 5, pp. 921932, 2002.

[124] V. A. Tronov, E. M. Konstantinov, E. Petrakou, S. Tsilimigaki, and S. M. Piperakis, "Nicotinamide "protects" resting lymphocytes exposed to hydrogen peroxide from necrosis but not from apoptosis," Cell Biology and Toxicology, vol. 18, no. 6, pp. 359-367, 2002.

[125] S. Coppola, C. Nosseri, V. Maresca, and L. Ghibelli, "Different basal NAD levels determine opposite effects of poly(ADPribosyl)polymerase inhibitors on $\mathrm{H} 2 \mathrm{O} 2$-induced apoptosis," Experimental Cell Research, vol. 221, no. 2, pp. 462-469, 1995.

[126] L. K. Klaidman, S. K. Mukherjee, T. P. Hutchin, and J. D. Adams, "Nicotinamide as a precursor for $\mathrm{NAD}^{+}$prevents apoptosis in the mouse brain induced by tertiarybutylhydroperoxide," Neuroscience Letters, vol. 206, no. 1, pp. 5-8, 1996.

[127] M. Leist, B. Single, A. F. Castoldi, S. Kühnle, and P. Nicotera, "Intracellular adenosine triphosphate (ATP) concentration: a switch in the decision between apoptosis and necrosis," Journal of Experimental Medicine, vol. 185, no. 8, pp. 14811486, 1997.

[128] M. Leist, B. Single, H. Naumann et al., "Inhibition of mitochondrial ATP generation by nitric oxide switches apoptosis to necrosis," Experimental Cell Research, vol. 249, no. 2, pp. 396-403, 1999.

[129] S. K. Mukherjee, L. K. Klaidman, R. Yasharel, and J. D. Adams Jr., "Increased brain NAD prevents neuronal apoptosis in vivo," European Journal of Pharmacology, vol. 330, no. 1, pp. 27-34, 1997.

[130] J. L. Lelli Jr., L. L. Becks, M. I. Dabrowska, and D. B. Hinshaw, "ATP converts necrosis to apoptosis in oxidantinjured endothelial cells," Free Radical Biology and Medicine, vol. 25, no. 6, pp. 694-702, 1998.

[131] W. Lieberthal, S. A. Menza, and J. S. Levine, "Graded ATP depletion can cause necrosis or apoptosis of cultured mouse proximal tubular cells," American Journal of Physiology, vol. 274, no. 2, pp. F315-F327, 1998.

[132] Z.-H. Ran, B. Rayet, J. Rommelaere, and S. Faisst, "Parvovirus $\mathrm{H}$-1-induced cell death: influence of intracellular 
NAD consumption on the regulation of necrosis and apoptosis," Virus Research, vol. 65, no. 2, pp. 161-174, 1999.

[133] C. L. Crowley, C. M. Payne, H. Bernstein, C. Bernstein, and D. Roe, "The NAD+ precursors, nicotinic acid and nicotinamide protect cells against apoptosis induced by a multiple stress inducer, deoxycholate," Cell Death and Differentiation, vol. 7, no. 3, pp. 314-326, 2000.

[134] G. De Murcia, A. Huletsky, and D. Lamarres, "Modulation of chromatin superstructure induced by poly(ADP-ribose) synthesis and degradation," Journal of Biological Chemistry, vol. 261, no. 15, pp. 7011-7017, 1986.

[135] T. Lindahl, M. S. Satoh, G. G. Poirier, and A. Klungland, "Post-translational modification of poly(ADP-ribose) polymerase induced by DNA strand breaks," Trends in Biochemical Sciences, vol. 20, no. 10, pp. 405-411, 1995.

[136] D. Martín-Oliva, F. O’Valle, J. A. Muñoz-Gámez et al., "Crosstalk between PARP-1 and NF- $\kappa$ B modulates the promotion of skin neoplasia," Oncogene, vol. 23, no. 31, pp. 5275-5283, 2004.

[137] A. S. Baldwin, "The transcription factor NF- $\kappa$ B and human disease," Journal of Clinical Investigation, vol. 107, no. 1, pp. 3-6, 2001.

[138] K. Brand, P. A. Bauerle, A. K. Walli, and D. Neumeier, "The role of NF-kappa B in the pathogenesis of atherosclerosis," Journal of Physiology, vol. 491P, pp. S2-S2, 1996.

[139] I. V. Budunova, P. Perez, V. R. Vaden, V. S. Spiegelman, T. J. Slaga, and J. L. Jorcano, "Increased expression of p50-NF$\kappa \mathrm{B}$ and constitutive activation of NF- $\kappa \mathrm{B}$ transcription factors during mouse skin carcinogenesis," Oncogene, vol. 18, no. 52, pp. 7423-7431, 1999.

[140] P. O. Hassa and M. O. Hottiger, "A role of poly (ADP-Ribose) polymerase in NF- $\kappa \mathrm{B}$ transcriptional activation," Biological Chemistry, vol. 380, no. 7-8, pp. 953-959, 1999.

[141] F. J. Oliver, J. Menissier-de Murcia, C. Nacci et al., "Resistance to endotoxic shock as a consequence of defective NF$\kappa \mathrm{B}$ activation in poly (ADP-ribose) polymerase-1 deficient mice," EMBO Journal, vol. 18, no. 16, pp. 4446-4454, 1999.

[142] D. Martin-Oliva, R. Aguilar-Quesada, F. O’Valle et al., "Inhibition of poly(ADP-ribose) polymerase modulates tumorrelated gene expression, including hypoxia-inducible factor-1 activation, during skin carcinogenesis," Cancer Research, vol. 66, no. 11, pp. 5744-5756, 2006.

[143] R. W. Pero, B. Axelsson, D. Siemann, D. Chaplin, and G. Dougherty, "Newly discovered anti-inflammatory properties of the benzamides and nicotinamides," Molecular and Cellular Biochemistry, vol. 193, no. 1-2, pp. 119-125, 1999.

[144] T. Nozaki, H. Fujihara, M. Watanabe et al., "Parp-1 deficiency implicated in colon and liver tumorigenesis induced by azoxymethane," Cancer Science, vol. 94, no. 6, pp. 497-500, 2003.

[145] E.-J. Yeo, Y.-S. Chun, and J.-W. Park, "New anticancer strategies targeting HIF-1,” Biochemical Pharmacology, vol. 68, no. 6, pp. 1061-1069, 2004.

[146] M. Ueda, "Telomerase in cutaneous carcinogenesis," Journal of Dermatological Science, vol. 23, no. 1, pp. S37-S40, 2000.

[147] M. Oren, "Decision making by p53: life, death and cancer," Cell Death and Differentiation, vol. 10, no. 4, pp. 431-442, 2003.

[148] C. L. Brooks and W. Gu, "Ubiquitination, phosphorylation and acetylation: the molecular basis for p53 regulation," Current Opinion in Cell Biology, vol. 15, no. 2, pp. 164-171, 2003.

[149] C. M. Simbulan-Rosenthal, D. S. Rosenthal, R. Luo, and M. E. Smulson, "Poly(ADP-ribosyl)ation of p53 during apoptosis in human osteosarcoma cells," Cancer Research, vol. 59, no. 9, pp. 2190-2194, 1999.

[150] C. M. Whitacre, H. Hashimoto, M.-L. Tsai, S. Chatterjee, S. J. Berger, and N. A. Berger, "Involvement of NAD-polyADPRibose) metabolism in p53 regulation and its consequences," Cancer Research, vol. 55, no. 17, pp. 3697-3701, 1995.

[151] L. A. Donehower, M. Harvey, B. L. Slagle et al., "Mice deficient for p53 are developmentally normal but susceptible to spontaneous tumours," Nature, vol. 356, no. 6366, pp. 215-221, 1992.

[152] K. G. McLure, M. Takagi, and M. B. Kastan, "NAD" modulates p53 DNA binding specificity and function," Molecular and Cellular Biology, vol. 24, no. 22, pp. 9958-9967, 2004. 

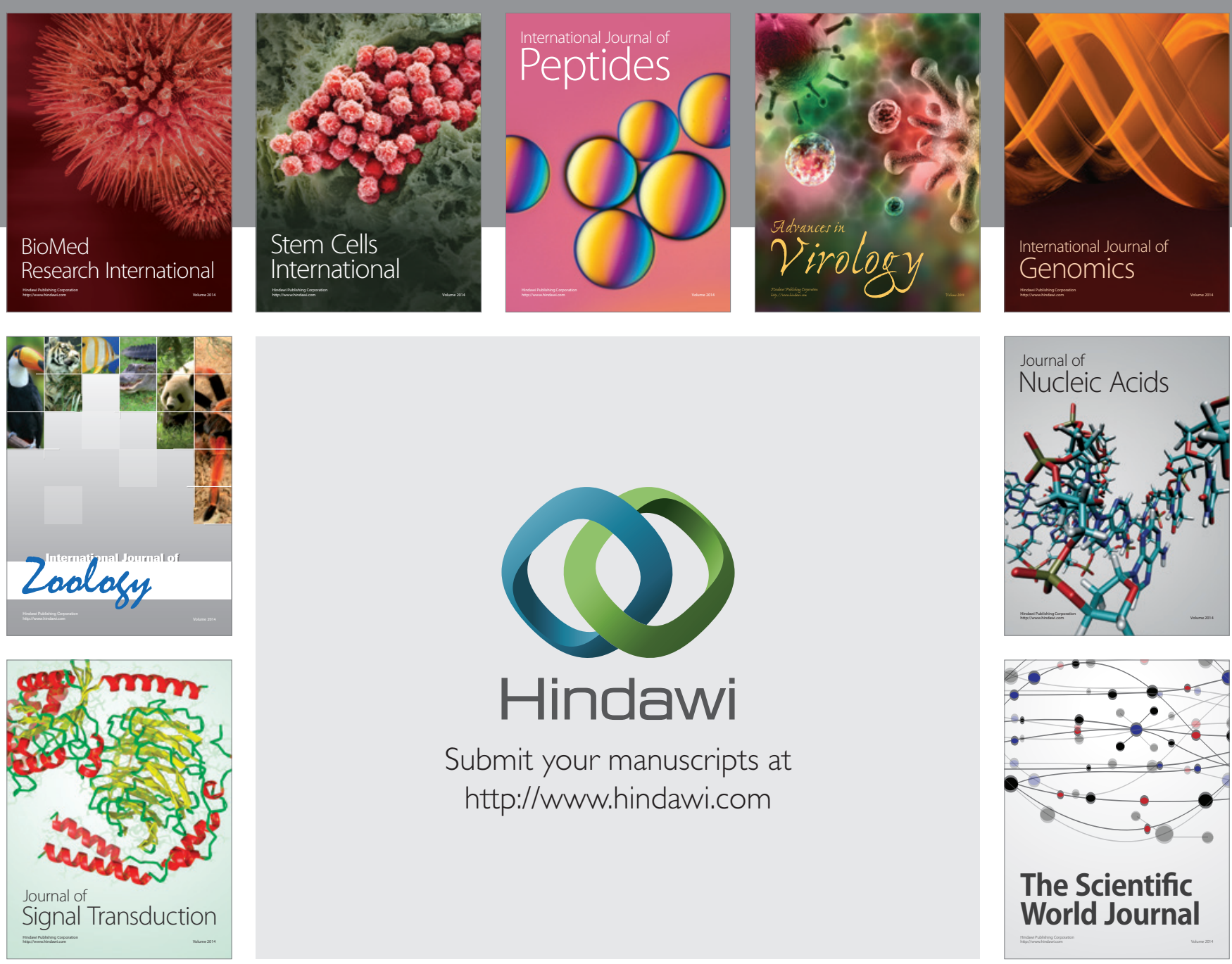

Submit your manuscripts at

http://www.hindawi.com
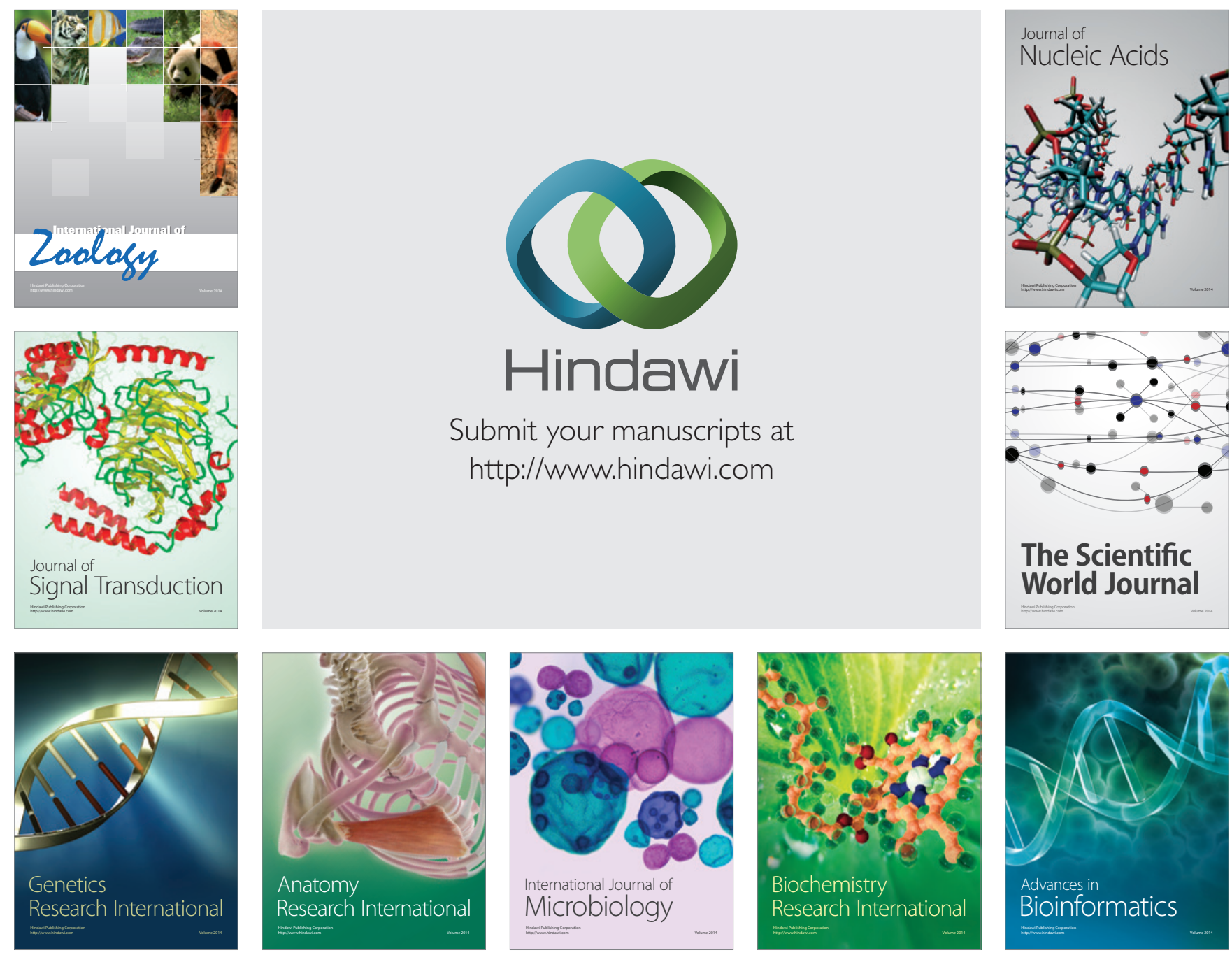

The Scientific World Journal
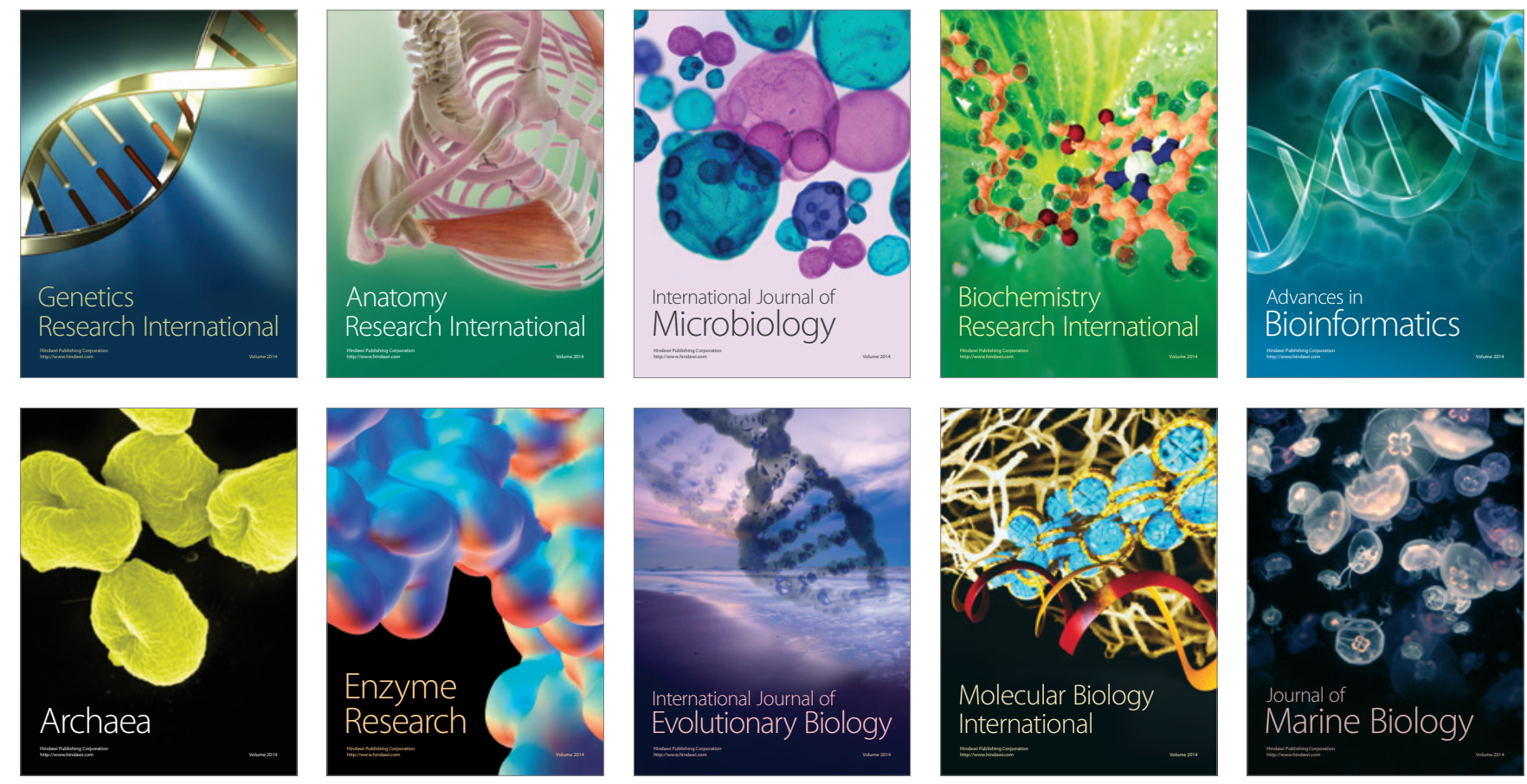